\title{
Optimization of PCR conditions to amplify microsatellite loci in the bunchgrass lizard (Sceloporus slevini) genomic DNA
}

\author{
Satya S Narina*, Christian A d'Orgeix, Brian L Sayre
}

\begin{abstract}
Background: Microsatellites, also called Simple Sequence Repeats (SSRs), repetitions of nucleotide motifs of 1-5 bases, are currently the markers of choice due to their abundant distribution in the genomes, and suitability for high-throughput analysis. A total of five different primer pairs were optimized for polymerase chain reaction (PCR) to amplify microsatellite loci in total genomic DNA of bunchgrass lizards (Sceloporus slevini) collected from three sites in southeastern Arizona; the Sonoita Plain, Chiricahua Mountains and Huachuca Mountains.

Findings: The primers used for current investigation were originally designed for the Eastern Fence Lizard (Sceloporus undulatus). Five primer pairs were selected based on annealing temperatures for optimizing the PCR conditions to amplify with bunchgrass lizards. Different concentrations of DNA and annealing temperature were optimized. While keeping other reagents constant, a DNA concentration, $37.5 \mathrm{ng}$ in the final reaction volume and PCR conditions of an initial denaturation of $94^{\circ} \mathrm{C}$ for five minutes, an annealing temperature of $55^{\circ} \mathrm{C}$ and final extension of $72^{\circ} \mathrm{C}$ for four minutes gave the best amplification for all the primer pairs.

Conclusions: Modifying the standard protocol for annealing temperatures and final extension time increases the success of cross amplification of specific microsatellite loci in the bunchgrass lizard. A loading volume of 5 ul DNA at a concentration of $10 \mathrm{ng} / \mathrm{ul}$ and a $2 \%$ agarose for gel electrophoresis were observed the best for cross amplification of selected five primer pairs on bunch grass lizard.
\end{abstract}

Trial Registration: The research was conducted with Arizona Game and Fish Department scientific collecting permits SP565256, SP657407 \& SP749119 to Dr. Christian A d'Orgeix.

\section{Background}

Small, isolated or bottlenecked populations suffer reduced genetic diversity increasing their potential for extinction [1]. Terrestrial "islands" such as mountain tops can function to isolate populations and reduce or halt gene flow between populations [2,3]. Slevin's bunchgrass lizard, Sceloporus slevini [4] inhabits both disjunct mountain grasslands in southeastern Arizona, southwestern New Mexico, the Sierra Madre Occidental of Mexico [5-7] and lower elevation grasslands in the Sonoita plain and Canelo grasslands in Arizona $[7,8]$. The disjunct population distribution of S. slevini and the recent bottleneck of a low elevation population [8] make

\footnotetext{
* Correspondence: satya.narina@ars.usda.gov

Department of Biology, Virginia State University, Petersburg, VA-23806,USA
}

it an ideal species to test a model of reduced genetic diversity within disjunct or bottlenecked populations.

A necessary preliminary step in examining the genetic characteristics of this species is to develop molecular species specific markers. Species-specific microsatellite markers [9] can be used to elucidate gene flow patterns and genetic diversity studies [10]. The SSR based microsatellite markers have been developed for a large number of plant [11,12] and animal [13] species and are increasingly being used for ascertaining germplasm improvement. The primer sequences used for the current project were originally developed for the Eastern Fence Lizard [14].

An important limitation, however, regarding use of microsatellites for polymorphism or genetic diversity studies is the prior need for optimization of PCR conditions for each SSR marker [15]. The Genomic DNA
() Biomed Central

C 2011 Narina et al; licensee BioMed Central Ltd. This is an open access article distributed under the terms of the Creative Commons Attribution License (http://creativecommons.org/licenses/by/2.0), which permits unrestricted use, distribution, and reproduction in any medium, provided the original work is properly cited. 
sequence variation between two different species might cause the variation in cross amplification success as the primers might identify a different region in the species of interest from the expected region. Required amplification may not be obtained using the recommended protocol due to involvement of many factors such as different types/brands of thermocyclers, reaction components, or even minor differences in thickness of walls of PCR tubes [16]. In addition, the quality and quantity of template DNA obtained with different DNA extraction protocols may also affect the PCR results.

The primer sequences selected for the current study were originally developed for S. undulatus, [14]. These primers were used to amplify the genomic DNA of S. slevini following the protocol published [14]. The cross amplification was not satisfactory even though S. slevini is a congener of $S$. undulatus. In order to reduce the time and cost involved in generation of ESTs and development of new primers from S.selvini, further protocol standardization was undertaken [16] by changing the annealing temperatures. PCR conditions were optimized for 5 SSR markers in S. slevini. In addition to PCR, agarose gel concentrations and sample loading volume were also optimized for clear visibility of microsatellites.

\section{Results}

The PCR conditions standardized for microsatellite amplification in this study were an initial denaturation at $94^{\circ} \mathrm{C}$ for five minutes; 35 cycles of denaturation $\left(94^{\circ} \mathrm{C}\right)$ for 30 seconds, annealing $\left(55^{\circ} \mathrm{C}\right)$ for 30 seconds, extension $\left(72^{\circ} \mathrm{C}\right)$ for one minute followed by final extension at $72^{\circ} \mathrm{C}$ for four minutes. The current study achieved excellent cross amplification performance using the standardized PCR conditions and was visualized on simple agarose gel electrophoresis, though the preferred method was the standard DNA sequencing gel electrophoresis. Previous studies have indicated that the optimal annealing temperature was $58-60^{\circ} \mathrm{C}\left(\mathrm{Ta} \geq 56^{\circ} \mathrm{C},[14]\right)$. However the PCR of selected markers at these conditions failed to amplify 45 out of the 50 samples tried. A series of PCRs were performed using these primer sets at multiple temperatures Viz., $53^{\circ} \mathrm{C}, 54^{\circ} \mathrm{C}, 55^{\circ} \mathrm{C}, 56^{\circ} \mathrm{C}, 57^{\circ} \mathrm{C}, 58^{\circ} \mathrm{C}, 59^{\circ} \mathrm{C}, 60^{\circ} \mathrm{C}$ and $61^{\circ} \mathrm{C}$ (Figure 1). The PCR products were not able to visualize on 1 to $1.5 \%$ agarose gels as solid bands. A series of fragments or a shadow of the band was observed instead of the solid single band. It was determined that it was necessary to electrophorese the samples on a $2 \%$ agarose gel inorder to eliminate the smaller fragments. The best amplification conditions for successful amplification of all the loci were at the lower annealing temperature of $55^{\circ} \mathrm{C}$ (Figure 2) and visualized on $2 \%$ agarose gel. The figures taken at annealing temperatures of $56^{\circ} \mathrm{C}$ and $59^{\circ} \mathrm{C}$ were also included in Figure1 to visualize and compare the improvement at $55^{\circ} \mathrm{C}$ in Figures 2 and 3 .

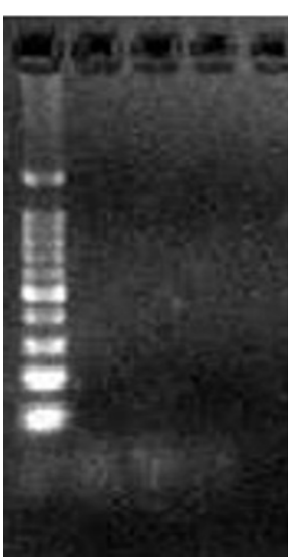

$59^{\circ} \mathrm{C}$

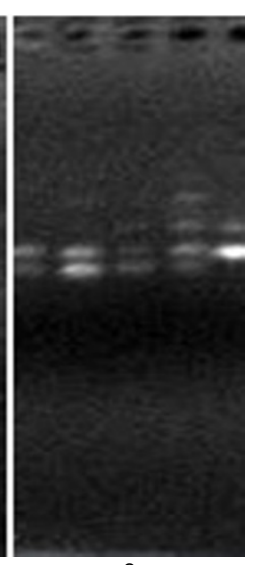

$56^{\circ} \mathrm{C}$
Figure 1 Illustration of failure to amplify at 59 and $56^{\circ} \mathrm{C}$

The sequencing gel wasn't used to visualize the microsatellite fragments as the objective of the current project is to test the cross amplification of primers. As the primers are successfully cross amplified, the ongoing project will use these primers to screen the rest of the population and observe the diversity.

There were 50 individuals scored for 5 markers (Table 1). Not all the individuals amplified for all the five markers. There are null alleles marked as 0 for each marker against each individual in table 1 . Individual $\mathrm{H} 10$ has no alleles for all the five loci tested. Only seven individuals are amplified at loci (marker) Sun_009 out of 50 tested. Among all the five loci tested, Sun_007, Sun_011 and Sun_012 are amplified in majority of the individuals. The loci Sun_011 and 012 are deviating from the expected size of 256 and

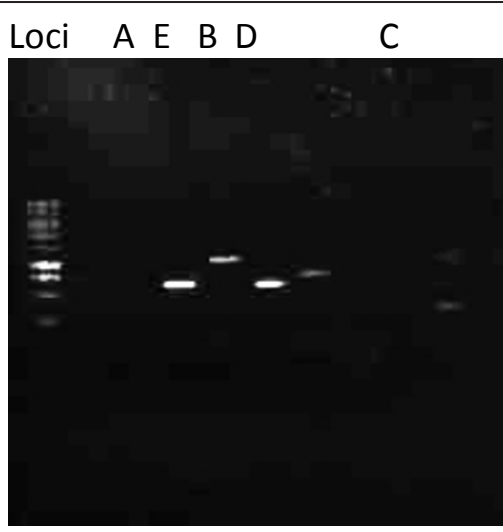

L 1223445667891011

Figure 2 Amplification (at $55^{\circ} \mathrm{C}$ annealing temperature) products of genomic DNA of Slevin's bunchgrass lizard (S. slevini) sample $\mathrm{H} 13$ on $2 \%$ agarose gel ran for one hour at 100 volts using 10 markers (1-10) and ladder (L); Lane1: Ladder; Lane2 -4,9 and 10: Empty; Lane 5: A; Lane 6: E; Lane 7: B; Lane 8: D; Lane 11: C. 


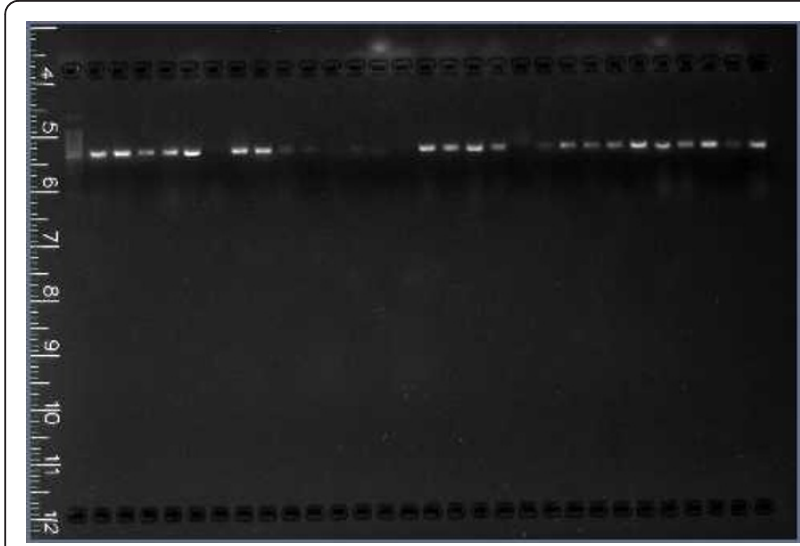

Figure 3 Amplification (at $55^{\circ} \mathrm{C}$ annealing temperature) products $(500 \mathrm{bp})$ of genomic DNA $(5 \mathrm{ul})$ of bunchgrass lizard sample numbers 17 to 46 on $2 \%$ agarose gel ran for 30 minutes at 100 volts using marker Sun_011.

248 respectively to $500 \mathrm{bp}$ and $600 \mathrm{bp}$ in our study 9 (Table 2).

\section{Discussion}

Though the SSR primer sets were selected from $S$. undulatus, a relative of $S$. slevini, it was necessary to optimize the PCR conditions for S. slevini in order to produce readable results. The current study reveals that it is critical to optimize the reaction conditions prior to largescale application of each locus, such as phylogenetic/ genetic diversity studies. Interestingly, as shown in Figures 2 and 3, a lower annealing temperature provided more specific amplification of the locus. The reason for this might be primer mismatches at higher temperatures [17] as the primers were originally created for a related species. At elevated temperatures the nucleation of the primer hybridization becomes more difficult, thus, the nonspecific target sites, with some mismatched base pairs, compete with the specific target sites for the primer hybridization. The ratio of primers binding to the correct sites decreases allowing mismatched priming of the polymerization. Once the mismatched priming occurs, extension is also faster at higher temperatures, and thus, there will be promotion of a nonspecific polymerization reaction. However, at 1 or $2^{\circ} \mathrm{C}$ lower annealing temperatures, nucleation would take place easily and there will be no or little competition of nonspecific sites with a couple of mismatches for the correct target sites [18].

The current investigation also observed the primers tested were all monomorphic on all the individuals tested except for H13. This could be due to their same origin or proximity within the taxon even though they were collected from two different elevation points/geographical locations. The phylogenetic studies of lizard [19] revealed a general pattern of strong character support for the monopoly of species groups and weak support for the relationship between them occurs in the trees from the molecular, morphological and combined data sets which might be due to the rapid speciation.

We found that the optimal temperature for cross hybridization of the primer sets for S. slevini was lower than the optimal temperature for the original species (S. undulatus). This work confirmed that microsatellite primers created for one species can be used in another species with optimization of the primer sets as done in several organisms previously [20,14]. By using this protocol, remaining markers will be studied and will be used to characterize different populations of bunchgrass lizard and to understand the evolutionary similarities between the populations.

\section{Conclusions}

The current study standardized a PCR protocol to amplify genomic DNA of S.slevini using the markers developed for $S$. undulatus. By increasing or decreasing the annealing temperatures and final extension time, the success of cross amplification of specific microsatellite loci increased markedly. The five markers tested were monomorphic in the bunch grass lizard. This is preliminary effort in bunchgrass lizard to generate markers due to non availability of funds and high throughput equipment in the lab. Out of the five, the loic Sun_007, Sun_011 and Sun_012 were usable for future screening as the frequency of null alleles was very low among the population tested. Further, these PCR products need to be sequenced to know the exact size of the amplified loci. These loci will be used to examine models of evolutionary history, gene flow patterns and inter and intrapopulation differences in S. slevini.

\section{Methods}

Research was conducted under Arizona Game and Fish Department scientific collecting permits SP565256, SP657407 \& SP749119 to Christian d'Orgeix. All applicable institutional and international animal care guidelines were followed.

Tissues from S. selvini were collected from two high elevation populations $(\mathrm{n}=16$, Huachuca Mts and $\mathrm{n}=15$, Chiricahua Mts) and one low elevation population ( $\mathrm{n}=6$, Appleton-Whittell Research Ranch, Elgin) in Arizona in 2006 and 2007. The lizards were caught by hand and approximately 2-4 mm of their tail tips were removed using tweezers. The lizards were then released at the site of capture. Besides these there were 13 collections in the department without geographical location information, also included for current investigation. Tissues were placed in 90\% isopropyl alcohol for 1-2 months. DNA was extracted using DNeasy tissue kit [21]. Approximately $25 \mathrm{mg}$ of tissue $(0.5 \mathrm{~cm}$ length of tail) was used for DNA 
Table 1 Cross Amplification using five markers for 50 collections (1-Present,0-Absent,- unknown) at the Department of Biology, V.S.U., Petersburg

\begin{tabular}{|c|c|c|c|c|c|c|}
\hline \multirow[b]{2}{*}{ Sample. No. } & \multirow[b]{2}{*}{ Name of the collection } & \multicolumn{5}{|c|}{ Markers } \\
\hline & & Sun_007 & Sun_009 & Sun_010 & Sun_011 & Sun_012 \\
\hline 1 & $\mathrm{~A} 1$ & - & 1 & 0 & 1 & 1 \\
\hline 2 & $\mathrm{~A} 2$ & 0 & 0 & 0 & 1 & 1 \\
\hline 3 & A3 & 0 & 0 & 0 & 1 & 1 \\
\hline 4 & A4 & 1 & 1 & - & 1 & 1 \\
\hline 5 & A5 & 1 & 0 & 0 & 1 & 1 \\
\hline 6 & A6 & 0 & 0 & - & 0 & 1 \\
\hline 7 & $\mathrm{H} 1$ & 0 & - & 0 & 0 & 1 \\
\hline 8 & $\mathrm{H} 2$ & 0 & 0 & 0 & 1 & 0 \\
\hline 9 & $\mathrm{H} 3$ & 0 & - & 0 & 1 & 1 \\
\hline 10 & $\mathrm{H} 4$ & 1 & 1 & 0 & 0 & 1 \\
\hline 11 & $\mathrm{H} 5$ & 0 & 0 & 0 & 1 & 0 \\
\hline 12 & $\mathrm{H} 6$ & 1 & 0 & 0 & 1 & - \\
\hline 13 & $\mathrm{H} 7$ & 1 & 1 & 0 & 1 & 1 \\
\hline 14 & $\mathrm{H} 8$ & 1 & 0 & - & 1 & 0 \\
\hline 15 & $\mathrm{H} 9$ & 0 & 0 & 0 & 1 & 0 \\
\hline 16 & $\mathrm{H} 10$ & 0 & 0 & 0 & 0 & 0 \\
\hline 17 & $\mathrm{H} 11$ & - & 0 & 0 & 1 & 0 \\
\hline 18 & $\mathrm{H} 13$ & - & 1 & 1 & 1 & 1 \\
\hline 19 & $\mathrm{H} 14$ & - & 1 & 0 & 1 & - \\
\hline 20 & $\mathrm{H} 15$ & 1 & 0 & 0 & 1 & 1 \\
\hline 21 & $\mathrm{H} 16$ & 1 & - & 0 & 1 & 0 \\
\hline 22 & $\mathrm{H} 17$ & 0 & 0 & 0 & 0 & 0 \\
\hline 23 & C1 & 1 & 0 & 0 & 1 & 1 \\
\hline 24 & $\mathrm{C} 2$ & 1 & - & 0 & 1 & 1 \\
\hline 25 & C3 & 1 & 0 & - & - & - \\
\hline 26 & C4 & 1 & 0 & 1 & - & 0 \\
\hline 27 & C5 & 1 & 0 & 1 & - & 0 \\
\hline 28 & C6 & 1 & 0 & 1 & - & 0 \\
\hline 29 & C7 & 1 & 0 & 1 & - & 0 \\
\hline 30 & $\mathrm{C} 8$ & 1 & 0 & 1 & 0 & 0 \\
\hline 31 & C9 & 1 & - & 1 & 1 & 0 \\
\hline 32 & $\mathrm{C} 10$ & 1 & 0 & 1 & 1 & 1 \\
\hline 33 & $\mathrm{C} 11$ & 1 & 0 & 1 & 1 & - \\
\hline 34 & $\mathrm{C} 12$ & 1 & 0 & - & 1 & - \\
\hline 35 & $\mathrm{C} 13$ & 1 & 1 & 0 & 0 & 1 \\
\hline 36 & C14 & 1 & 0 & - & - & - \\
\hline 37 & C15 & 1 & - & - & 1 & 1 \\
\hline 38 & E1 & 1 & 0 & 0 & 1 & - \\
\hline 39 & $\# 1$ & 1 & 0 & 0 & 1 & 1 \\
\hline 40 & $\# 2$ & 1 & 0 & 0 & 1 & 1 \\
\hline$\overline{41}$ & $\# 3$ & 1 & 0 & 0 & 1 & 1 \\
\hline 42 & $\# 4$ & 1 & 0 & - & 1 & 1 \\
\hline 43 & $\# 5$ & 1 & - & 0 & 1 & 1 \\
\hline 44 & $\# 6$ & 1 & 0 & 0 & - & - \\
\hline 45 & $\# 7$ & 1 & 0 & 0 & 1 & 1 \\
\hline
\end{tabular}


Table 1 Cross Amplification using five markers for 50 collections (1-Present,0-Absent,- unknown) at the Department of Biology, V.S.U., Petersburg (Continued)

\begin{tabular}{lllllll}
\hline 46 & $\# 8$ & 1 & 0 & 0 & 1 & - \\
\hline 47 & $\# 9$ & 1 & 0 & 0 & 1 \\
\hline 48 & $\# 10$ & 1 & 0 & - & 1 \\
\hline 49 & $\# 11$ & 1 & 0 & 1 & 0 & - \\
\hline 50 & $\# 13$ & 1 & - & 1 & - \\
\hline
\end{tabular}

(A-Appleton; H-Huachuca; C-Chiricahua; E-East France).

isolation using the protocol [21] and the extracted DNA samples were stored at $-20^{\circ} \mathrm{C}$ for future use.

DNA was quantified at $260 \mathrm{~nm}$ wavelength by using Smart spec, 3000 spectrophotometer (http://www.bio-rad. com/LifeScience/pdf/Bulletin_2634.pdf) and dilutions of known concentrations were prepared. Absorbance ratios of the extracted genomic DNA at $260 \mathrm{~nm}$ and $280 \mathrm{~nm}$ were ranging from 1.34 to 2.00 . Quality of DNA was also confirmed by electrophoresing DNA on 1.1\% agarose gel. Out of total 39 SSR markers previously reported [14] in Sceloporus undulatus, only 10 markers were tested in this study.

The PCRs were performed in the absence of oil for 50 $\mu \mathrm{L}$ of reaction volume using simple PCR reaction in BioRad's "i"cycler. Reaction mixture included template DNA (10 ng) solution, forward and reverse primers (0.15-0.30 $\mu \mathrm{M}$ ), and Platinum PCR Supermix (Invitrogen Corporation). The cycling reactions were conducted for $5 \mathrm{~min}$ at $94^{\circ} \mathrm{C}$, followed by 35 cycles of $30 \mathrm{sec}$ denaturation step at $94^{\circ} \mathrm{C}, 0.5-1.0 \mathrm{~min}$ primer annealing step at varying temperatures of $53^{\circ} \mathrm{C}, 54^{\circ} \mathrm{C}, 55^{\circ} \mathrm{C}, 56^{\circ} \mathrm{C}, 57^{\circ} \mathrm{C}, 58^{\circ} \mathrm{C}, 60^{\circ} \mathrm{C}$ and $61^{\circ} \mathrm{C}$, and 4 min extension step at $72^{\circ} \mathrm{C}$. The amplification of the markers were detected by running the amplicons on $2 \%$ agarose gel in $1 \mathrm{X}$ TBE buffer, stained with ethidium bromide (500 $\mathrm{ng} / \mathrm{mL}$ ), visualized and photographed using VersaDoc Imaging system Model 4000 (BIORAD suppliers). All gels were run at $106 \mathrm{~V}$ constant power supply for 1-2 hours. We tried loading different volumes of DNA (1-5 ul) with different concentrations from 5 to10 $\mathrm{ng} / \mathrm{ul}$. The gel images were clear with solid bands at $10 \mathrm{ng} / \mathrm{ul}$ concentration and loading volume of $5 \mathrm{ul}$.

The Primer pairs Sun_019, 020, 030, 033 and 038 were not amplified on bunchgrass lizard samples using

Table 25 SSR markers with their observed and expected size of PCR products

\begin{tabular}{llll}
\hline $\begin{array}{c}\text { Code to the } \\
\text { marker }\end{array}$ & Locus Id & $\begin{array}{c}\text { Observed size (bp) of } \\
\text { the PCR product (Range) } \\
\text { on 2\% agarose gel }\end{array}$ & $\begin{array}{c}\text { Size } \\
\text { expected }\end{array}$ \\
\hline A & Sun_007 & $300-400$ & 317 \\
\hline B & Sun_009 & $300-400$ & 453 \\
\hline C & Sun_010 & 200 & 259 \\
\hline$D$ & Sun_011 & 500 & 256 \\
\hline$E$ & Sun_012 & 600 & 248 \\
\hline
\end{tabular}

published protocol as well as our standardized protocol at $55^{\circ} \mathrm{C}$ annealing temperature (Figure 2). Therefore only five primer pairs were selected for current diversity studies and the observed and expected band sizes for each locus were given in Table 2.

\section{Acknowledgements}

Research was conducted under Arizona Game and Fish scientific collecting permits to Christian d'Orgeix. All applicable institutional animal care guidelines were followed. Field assistance was provided by Tierra Alvin, N. Danielle Bridgers, Sarecia Harris, Jonathan Jeffreys, and Larry Powell. Funding was provided to Tierra Alvin, N. Danielle Bridgers, and Sarecia Harris by the Louis Stokes Alliance for Minority Participation, and to N. Danielle Bridgers under an Ariel Appleton Research Fellowship. Linda Kennedy at the National Audubon Society Appleton-Whittell Research Ranch provided logistic support.

\section{Authors' contributions}

SN designed the experiment, carried out the molecular genetic studies and drafted the manuscript. CD and BS participated in preparation of the manuscript. All authors read and approved the final manuscript.

\section{Competing interests}

The authors declare that they have no competing interests.

Received: 8 September 2010 Accepted: 31 January 2011 Published: 31 January 2011

\section{References}

1. Frankham R, Ballou JD, Briscoe DA: A Primer of Conservation Genetics. Cambridge University Press, Cambridge, United Kingdom; 2004.

2. Grant PR: Evolution on Islands. Oxford University Press, Oxford; 1998.

3. Tennessen JA, Zamudio KR: Genetic differentiation among mountain island populations of the striped plateau lizard, Sceloporus virgatus (Squamata: Phrynosomatidae). Copeia 2008, 3:558-564.

4. Smith HM, Watkins-Colwell GJ, Liner EA, Chiszar D: Sceloporus scalaris auctorum a superspecies (Reptilia: Sauria). Bulletin of the Maryland Herpetological Society 1996, 32:70-74.

5. Van Denburg J: The reptiles of western North America. Vol. I. Lizards. Occasional Papers of the California Academy of Sciences 1922, 10:1-611.

6. Ballinger RE, Congdon JD: Status of the bunch grass lizard, Sceloporus scalaris, in the Chiricahua Mountains of southeastern Arizona. Bulletin of the Maryland Herpetological Society 1996, 32:67-69.

7. Stebbins RC: A Field Guide to Western Reptiles and Amphibians. Houghton-Mifflin, Boston; 32003.

8. Smith HM, Chiszar D, Chiszar A, Auth DL, Auth J, Henke C, Bock CE, Bock JH, Ryback JA, Holland RL, Bonnie K: Slevin's bunch grass lizard (Sceloporus slevini) decimated on the Sonoita Plain, Arizona. Herpetological Review 1998, 29:225-226.

9. Johansson M, Ellegren $H$, Adersson L: Cloning and characterization of highly polymorphic porcine microsatellites. Heredity 1992, 83:196-198.

10. Tóth G, Gáspári Z, Jurka J: Microsatellites in different eukaryotic genomes. Genome Res 2000, 10:967-981.

11. Senior ML, Heun M: Mapping maize microsatellites and polymerase chain reaction confirmation of the targeted repeats a CT primer. Genome 1993, 36:884-889. 
12. Narina S, Andebrhan T, Mohamed A, Asiedu R: Development of genomic tools for Improvement of yam (Dioscorea alata L). International Plant and Animal Genomic Conference 2007.

13. Banks Ma, Blouin MS, Baldwin BA, Rashbrook VK, Fitzerald HA, Blankenship MS, Hedgecock D: Isolation and inheritance of novel microsatellites in Chinook salmon (Oncorhynchus tschawytscha). Journal of Heredity 1999, 90:2.

14. Rosenblum ER, Belflore CM, Mortiz C: Primer Note: Anonymous nuclear markers for the eastern fence lizard, Sceloporus undulates. Molecular Ecology Notes 2007, 7:113-116.

15. Ogliari JB, Boscariol RL, Camargo LEA: Optimization of PCR amplification of maize microsatellite loci. Genet. Mol. Biol 2000, 23(2):395-398.

16. Dograr N, Akkaya MS: Optimization of PCR amplification of wheat simple sequence repeat DNA markers. Turk. J. Biol 2001, 25:153-158.

17. Nurdan D, Mahinur SA: Optimization of PCR Amplification of Wheat Simple Sequence Repeat DNA Markers. Turk J Biol 2001, 25:153-158.

18. Bryan GJ, Collins AJ, Stephenson P, Orry A, Smith JB, Gale MD: Isolation and characterization of microsatellites from hexaploid bread wheat. Theor. Appl. Genet 1997, 94:557-563.

19. Weins JJ, Reeder WT: Phylogeny of the spiny lizards (Sceloporus) based on molecular and morphological evidence. Herpetological monograph 1997, , 11: 1-101, [0733-1347].

20. Tautz D: Hypervariability of simple sequences as a general source for polymorphic DNA markers. Nuceic Acids Res 1989, 17:6463-6471.

21. Qiagen DNeasy ${ }^{\circledR}$ Tissue Handbook: Protocol for isolation of total DNA from animal tissues. QIAGEN, Valencia, California, USA; 2004, 18-20.

doi:10.1186/1756-0500-4-26

Cite this article as: Narina et al: Optimization of PCR conditions to amplify microsatellite loci in the bunchgrass lizard (Sceloporus slevini) genomic DNA. BMC Research Notes 2011 4:26.

\section{Submit your next manuscript to BioMed Central and take full advantage of:}

- Convenient online submission

- Thorough peer review

- No space constraints or color figure charges

- Immediate publication on acceptance

- Inclusion in PubMed, CAS, Scopus and Google Scholar

- Research which is freely available for redistribution

Submit your manuscript at www.biomedcentral.com/submit 